\title{
Oxidation behaviors of the Photovoltaic Ribbon in the Spent Photovoltaic Module
}

\author{
Sae-Kwon Heo, Woo-Jin Lee, Seoung-Sik Jeoung, Jei-Pil Wang*
}

\begin{abstract}
The solar cell has been in the spotlight as new renewable energy. Considering its life expectancy, a large quantity of the spent module will be produced after 2020, so many studies are being conducted on the recovery of valuable resources from the spent photovoltaic module. In particular, there are not many studied conducted on the photovoltaic robbin recovered from the spent photovoltaic module. Therefore, in this study, experiments were conducted to verify the oxidation behaviors in the coating layer of the photovoltaic ribbon recovered from the spent photovoltaic module. The oxidation behaviors were observed for 24 hours at the temperature of $100^{\circ} \mathrm{C}, 300^{\circ} \mathrm{C}, 500^{\circ} \mathrm{C}$ and $700^{\circ} \mathrm{C}$ using TGA, and the oxide layer formation and the component change in respective sections were analyzed using SEM and EDC according to the holding time of $1 \mathrm{hr}, 2 \mathrm{hrs}, 4 \mathrm{hrs}$ and $8 \mathrm{hrs}$ at the temperature of $500^{\circ} \mathrm{C}$ showing the most distinctive oxidation behavior.
\end{abstract}

\section{Introduction}

Due to the depletion of fossil fuels and the use of fuels because of the industrial development, the global warming issues have arisen. Therefore, the new renewable energy for solving the environmental issues and energy depletion are receiving much attention. In particular, the photovoltaic energy is the most promising and technically matured sector in the renewable energy sector.1) The photovoltaic module showing superior energy efficiency does not produce pollutants, noise and toxic gases. 2) Since the photovoltaic module has a relatively long life expectancy of 20-25 years, many countries have already gained economic benefits from the photovoltaic industry and thus the photovoltaic module is expected to continue to grow in future.

According to the report of McKinsey (Solar Power; Darkest before down), the cumulative capacity of the installed photovoltaic facilities is forecast to reach 400 $600 \mathrm{GW}$ in 2020.3) [Figure 1-1] shows the trend of the photovoltaic facility installation on an annual basis. In Korea, the cumulative capacity of the installed photovoltaic facilities reached $680 \mathrm{MW}$ in 2010 , and its scale is expanding on a continuous basis. The supply of the photovoltaic module with the average life expectancy of 15 years started in the early 1990s and the quantity of the photovoltaic module has steadily continued to increase, reaching approximately $130,000 \mathrm{MT}$ in 2023 on a cumulative basis.4)

Sae-Kwon Heo, Woo-Jin Lee, Seoung-Sik Jeoung, Jei-Pil Wang*

Department of Metallurgical Engineering, Pukyong National University

Republic of Korea

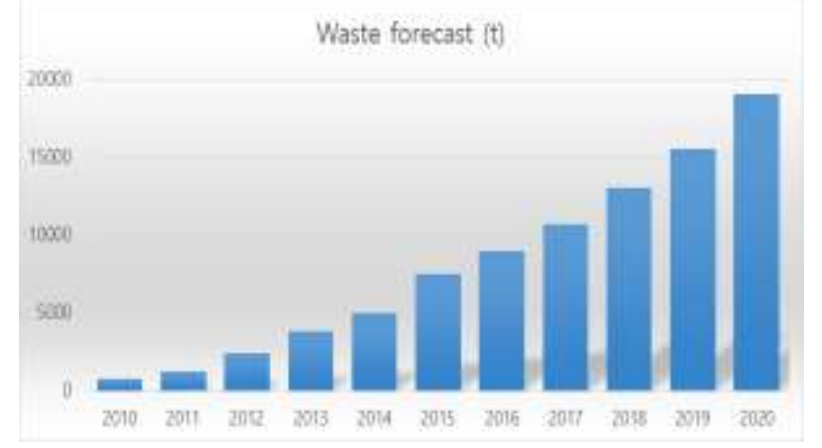

Figure 1-1 cumulative capacity of the installed photovoltaic facilities

The importance of the recycling of photovoltaic modules has merged and many studies are being conducted on the recovery of the valuable resources from the spent photovoltaic module and the recycling of them worldwide.6) 9) However, there are not many studies conducted on the recovery of the valuable metals from the spent PV ribbon in the photovoltaic module. Therefore, the recovery and recycling of the valuable metals from the PV ribbon in the spent photovoltaic module is expected to make great contribution to the localization of the economic resources. 11) 14)

This study is a base study on the recycling the PV ribbon from the spent photovoltaic module, in particular, the oxidation behaviors according to conditions of heat treatment conditions intended to separate the coating layer from the PV ribbon. The heat treatment experiments were conducted by varying the temperature from $100^{\circ} \mathrm{C}$ to $800^{\circ} \mathrm{C}$, and the oxidation behaviors in the PV ribbon was measured using TGA (thermogravimetric analysis); the surface oxidation behavior in the PV ribbon according to the holding time of from $1 \mathrm{hr}$ to $8 \mathrm{hrs}$ at the temperature of $500^{\circ} \mathrm{C}$ was observed using SEM (scanning electron microscopy); and the chemical composition of the oxidized PV ribbon from the surface to the inside part was analyzed using EDX (energy dispersive X-ray microscopy).

\section{MATERIALS FOR EXPERIMENT}

[Figure 2-1] shows the structure of the commercially available PV ribbon products. Looking at the structure, the $\mathrm{Cu}$ wire exists inside and the coating layer wraps the outside uniformly. Looking at the shape, the width is approximately $1 \mathrm{~mm}-4 \mathrm{~mm}$ and the thickness is approximately $0.1 \mathrm{~mm}$ $0.25 \mathrm{~mm}$ at $0.1 \mathrm{~mm}$. In the construction of the coating layer, the surface of the high-purity $\mathrm{Cu}$ wire is coated with $64 \% \mathrm{Sn}$ and $36 \% \mathrm{~Pb}$ and a small amount of $\mathrm{Au}(0.2 \sim 0.4 \%)$. First, confirm that you have the correct template for your paper size. This template has been tailored for output on the USletter paper size. If you are using A4-sized paper, please close this file and download the file for "MSW A4 format". 
Proc. of Sixth International Conference On Advances in Applied Science and Environmental Engineering - ASEE 2016 Copyright (C) Institute of Research Engineers and Doctors. All rights reserved. ISBN: 978-1-63248-108-5 doi: 10.15224/ 978-1-63248-108-5 -36
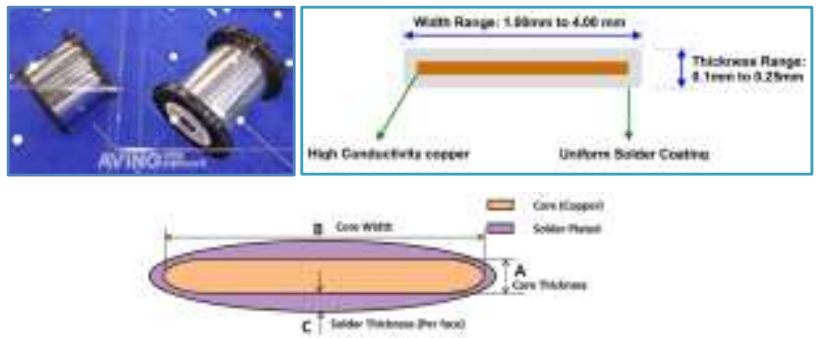

Figure 2- 1. The structure of PV ribbon product

[Figure 2-2] shows the results of an analysis of the components of the PV ribbon from KOSBON which is the manufacturer of PV ribbon. The cross-section of the PV ribbon was observed using SEM, and the coating layer was analyzed for chemical composition using EDX. The $\mathrm{Cu}$ is located in the middle part; the coating alloy layer wraps the both sides uniformly; and the thickness is approximately 30 $\mu \mathrm{m}$. The results of an analysis of the coating layer using EDX showed that it was composed of $68.79 \% \mathrm{Sn}$ and $31.21 \% \mathrm{~Pb}$. The chemical composition of the commercially available PV ribbon was analyzed using ICP. The results showed it contained $87.75 \% \mathrm{Cu}, 5.25 \%$ lead, $6.15 \% \mathrm{Sn}$ and a small amount of $\mathrm{Nb}$ and $\mathrm{Ag}$.
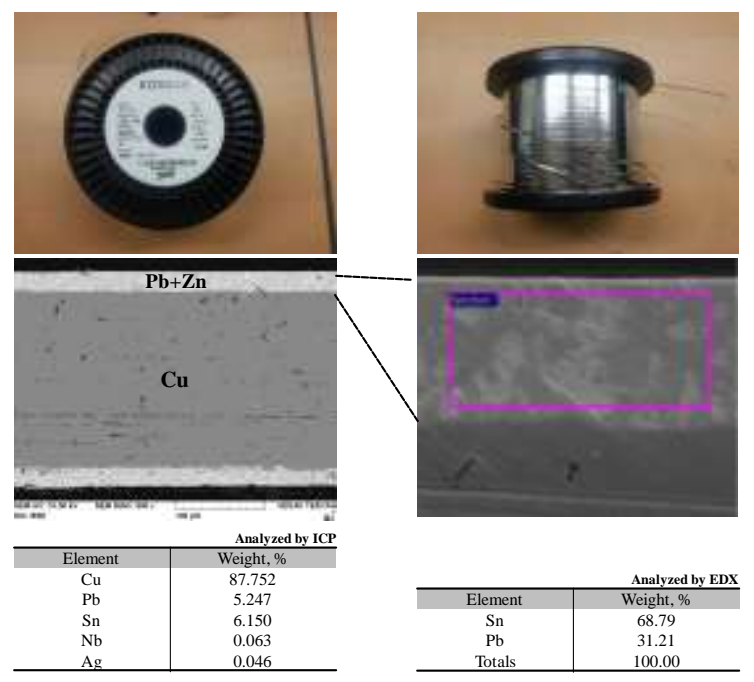

Figure 2- 2. An analysis of the chemical composition of the commercially available PV ribbon (Equipment used for analysis: EDX, ICP)

\section{EXPERIMENTAL METHOD}

[Figure 3-1] shows the schematic diagram of TGA used to measure the oxidation of the coating layer in the PV ribbon. For the oxidation of the coating layer, oxygen and argon gases were respectively used, and to remove the moisture inside the gases before the injection of gases, these gases were pushed through drierite $\left(\mathrm{CaSO}_{4}\right)$. The flow rate of the gases was adjusted to fix the partial pressure of oxygen using MF and then they were injected into TGA reactor. To prevent the coating layer from oxidation, only argon gas was injected until the desired temperature for measurement was reached and then an oxygen gas was injected for oxidation experiment when the desired temperature was reached. The weight of the sample was automatically programmed and the data was quantified for an analysis of the oxidation behaviors after the completion of experiment.
<Table 1-1> shows the changes in the Gibbs free energy values for the oxidation reaction according to the temperature of $\mathrm{Pb}$ and $\mathrm{Sn}$. It shows the Gibbs free energy values when $\mathrm{Pb}$ and $\mathrm{Sn}$ form the oxides that can be generated through oxygenation. It is thermodynamically predicted that $\mathrm{Pb}$ and $\mathrm{Sn}$ may transform their phase to $\mathrm{PbO}$, $\mathrm{PbO}_{2}, \mathrm{SnO}$ and $\mathrm{SnO}_{2}$ relatively easily.

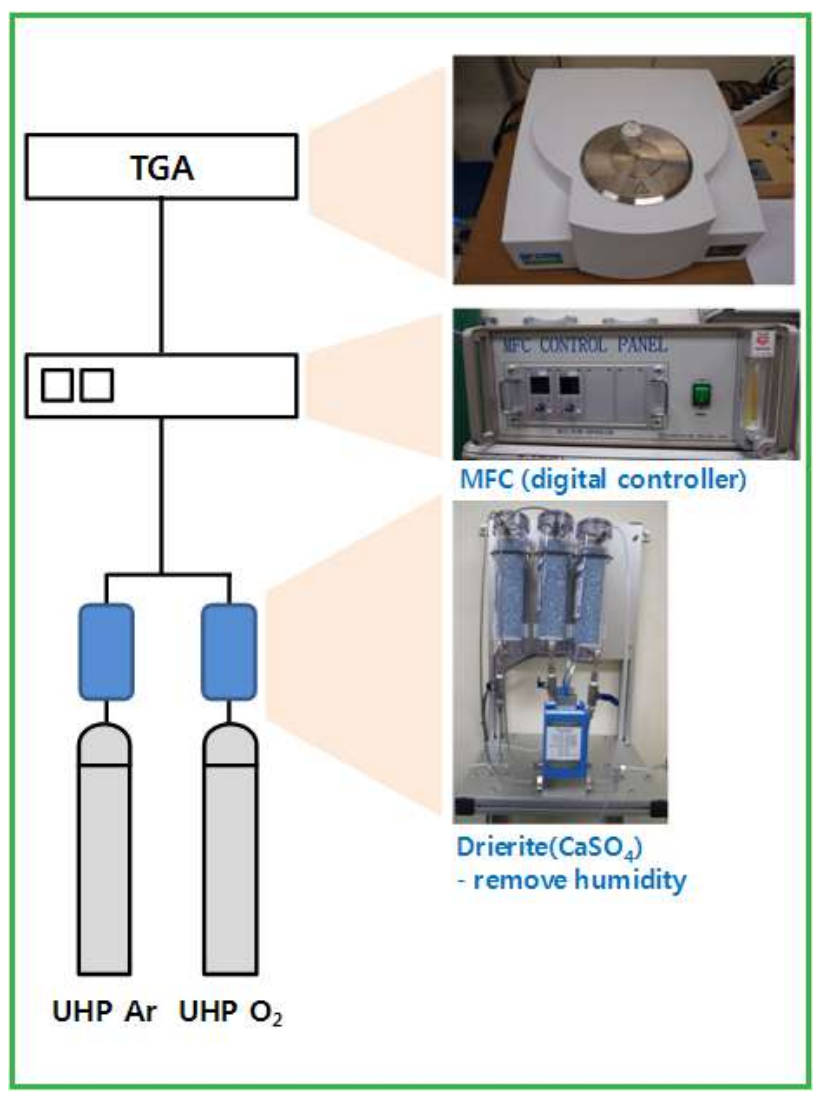

Figure 3- 1. The schematic diagram of TGA for oxidation experiment

TABLE 1-1. GIBBS FREE ENERGY VALUES OF THE OXYGENATION ACCORDING TO THE TEMPERATURE OF PB AND SN

\begin{tabular}{|c|c|c|c|c|c|c|c|c|c|c|}
\hline \multicolumn{5}{|c|}{$20 \mathrm{~b}+02 \mathrm{~g})=20 \mathrm{bO}$} & \multicolumn{6}{|c|}{$\mathrm{Pb}+\mathrm{O} 2(\mathrm{~g})=\mathrm{PbO2}$} \\
\hline$T$ & dettan- & detas & dettas & K & $\top$ & & delant & detios & deitag & \\
\hline & kcal $\quad \mathrm{g}$ & calk & kesi & & $c$ & & $\mathrm{kcd}$ & $\mathrm{cos} / \mathrm{x}$ & kcal & \\
\hline & .104285 & -47.342 & 2.91 .354 & $1.26 \mathrm{E}+7$ & & 0 & .65 .624 & 47,445 & 5.52 .665 & $136 E+42$ \\
\hline & -104.056 & .46 .631 & .86655 & $55.72 \mathrm{E} \cdot 5 \mathrm{C}$ & & 100 & -65.469 & -46972 & -47.942 & \\
\hline & -103.778 & .45 .974 & .82026 & $67.78 \mathrm{E} \cdot 37$ & & & -65221 & -46366 & .43 .274 & \\
\hline & -103.483 & .45 .408 & $-77,457$ & $3.45 E+29$ & & 350 & -44936 & -45832 & -39663 & \\
\hline & -105.494 & $.48 \pi 74$ & .72 .662 & 3.928 & & 400 & -65.794 & & & \\
\hline & .105 .154 & .48 .303 & .678 & & & 0 & & & & \\
\hline & -104.748 & -4781 & .630 & 5.50 & & 0 & -65 & & & \\
\hline & -104275 & .47 .298 & .58 .2 & & & 0 & & & -19 & \\
\hline & -103.736 & $.46 \mathrm{mz}$ & .53 .543 & 8.04 & & 0 & -44426 & 45 ? & -15.382 & \\
\hline & .90 .998 & .35 .679 & .49 .042 & 1.37 & & & .4063 & 45 & .10 .828 & \\
\hline & 90.025 & .34 .965 & -45 & & & & 63.704 & -45.084 & -6.305 & \\
\hline \multicolumn{5}{|c|}{$\operatorname{sen}+02(g)=\operatorname{sen} 2$} & \multicolumn{6}{|c|}{$5 n+O r i g l=5 n O z$} \\
\hline & 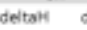 & detas of & detal & k & & & 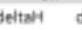 & deltas & deltac & \\
\hline & kesal o & & $\mathrm{kcal}$ & & $c$ & & $\mathrm{cos}$ & $\cos / x \quad 1$ & keal & \\
\hline 0 & -138026 & -49.44 & -124521 & $4.35 E+99$ & & 0 & .138 .026 & .49 .44 & -124.521 & $435 E+99$ \\
\hline 100 & -138.034 & -49.49 & -119.567 & $108 \mathrm{E}$ & & 100 & -1380 & .49 .29 & & \\
\hline 200 & -197968 & -49099 & -114637 & & & 200 & & -49099 & & \\
\hline 300 & -139.328 & -52011 & -109519 & & & 900 & -139 & & & \\
\hline 400 & -138.994 & & $-104,344$ & & & 40 & & & & \\
\hline 500 & -1386 & & & $1.12 \mathrm{E}$ & & 500 & & & & \\
\hline 600 & -138.2 & .50 .4 & .943 & & & $\infty 0$ & & & & \\
\hline 700 & -137.780 & $-50,002$ & & & & 700 & -137 & & -9913 & \\
\hline 800 & -137.3 & $.49:$ & -34 & & & $B 00$ & & & & \\
\hline 900 & -136889 & & .79 & & & 900 & & & & \\
\hline 1000 & -136.417 & .48776 & .74319 & $5.74 E+12$ & & 1000 & -136.417 & -49.776 & .74 .319 & $5.74 \varepsilon+12$ \\
\hline
\end{tabular}




\section{RESUTLS OF EXPERIEMENT}

[Figure 4-1] schematizes the changes in the weight of the commercially available PV ribbon according to temperature measured using TGA. At the temperature of $100^{\circ} \mathrm{C}, 300^{\circ} \mathrm{C}$, $500^{\circ} \mathrm{C}$ and $700^{\circ} \mathrm{C}$, an oxygen gas was injected at the rate of $20 \mathrm{Ncc} / \mathrm{min}$ for 24 hours for the measurement in the oxygen atmosphere. As a result, it was found that with the increase in temperature, the weight of PV ribbon increased, showing a sharp increase particularly at $500^{\circ} \mathrm{C}$ and $700^{\circ} \mathrm{C}$. This indicates the oxidation rate increases in the relatively high temperature range, and the oxidation effect of the coating layer is not significant at the low temperature of $100^{\circ} \mathrm{C}$ and $300^{\circ} \mathrm{C}$. Looking at the oxidation behaviors over the entire temperature range, they follow the parabolic rate law, which is the phenomenon in which the oxidation rate increase rapidly in the initial stage and then decreases over time. The rate law of the parabolic rate can be expressed as the reaction formula below.

- All oxidation plots were followed as parabolic rate law

$$
\begin{gathered}
\frac{\mathrm{dx}}{\mathrm{dt}}=\frac{k_{p}}{x} \\
x^{2}=2 k_{p} t+C
\end{gathered}
$$

- $\mathrm{kp}$ : parabolic rate constant, $\mathrm{x}$ : time, $\mathrm{C}$ : integration constant

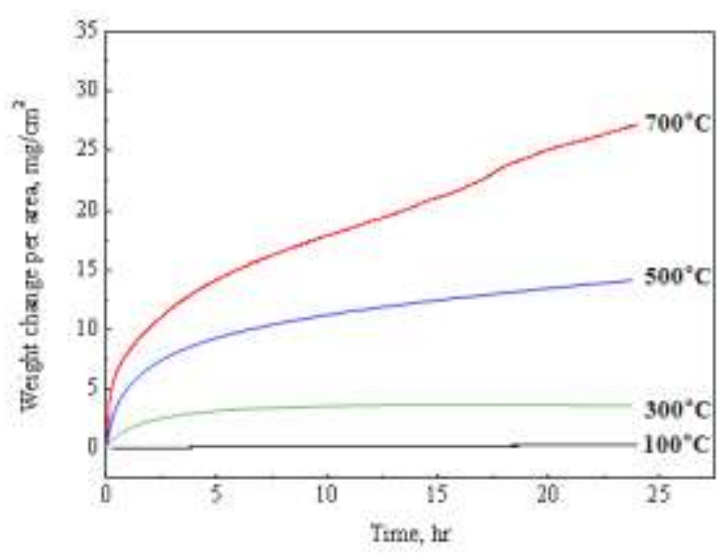

Figure 4- 1. The changes in the weight of the commercially available PV ribbon according to temperature

[Figure 4-2] shows the shape of the oxide layer of the commercially available PV ribbon observed at $500^{\circ} \mathrm{C}$ using SEM. The coating layer coated on both sides uniformly before oxidation transformed into the wisker shape during the process of oxidation. The experiment was conducted by varying the oxidation time $1 \mathrm{hr}, 2,4$ and $8 \mathrm{hrs}$. The results showed that the oxide scale layer become thick from the oxidation time of $4 \mathrm{hrs}$, and the scale was separated from the PV ribbon. After the oxidation of $8 \mathrm{hrs,} \mathrm{it} \mathrm{was}$ observed the coating layer was almost oxidized and the oxide scale was separated from the base material.

[Figure 4-3] shows the shape of the commercially available PV ribbon sample taken after 2-hr oxidation at the temperature of $500^{\circ} \mathrm{C}$, the distribution of the chemical composition of the oxide layer analyzed by EDS line scanning and the result of an analysis of the chemical composition of respective sections in the oxide later and base material. The thickness of the coating layer of the original sample before the formation of oxide layer was approximately $30 \mathrm{um}$, but it increased to approximately 40um in the samples that went through heat treatment. As a result of the line scanning of samples, $\mathrm{Cu}$ was generally detected from the outside to the inside of the oxide layer. Sn was mainly detected outside and $\mathrm{Pb}$ was mainly detected in the middle part.

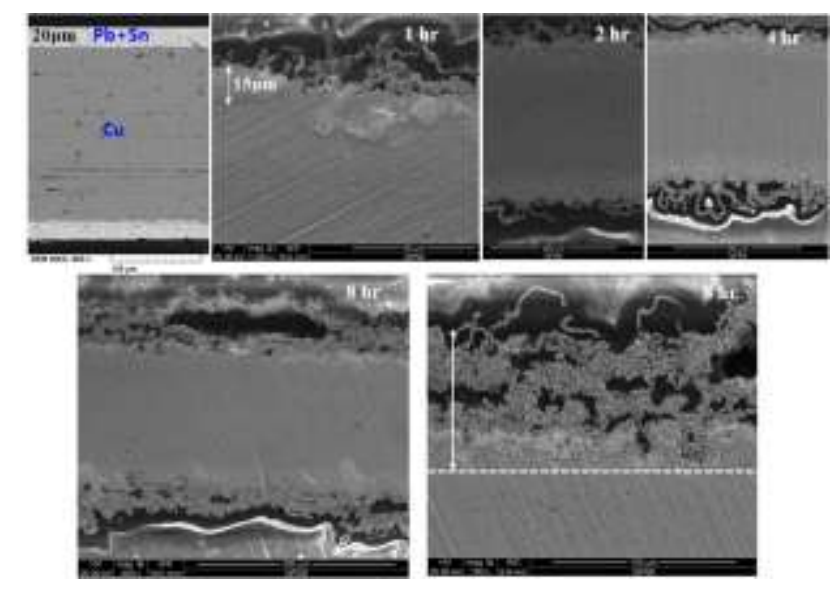

Figure 4-2. The shape of the oxide later in the commercially available PV ribbon according to oxidation time at the temperature of $500{ }^{\circ} \mathrm{C}$
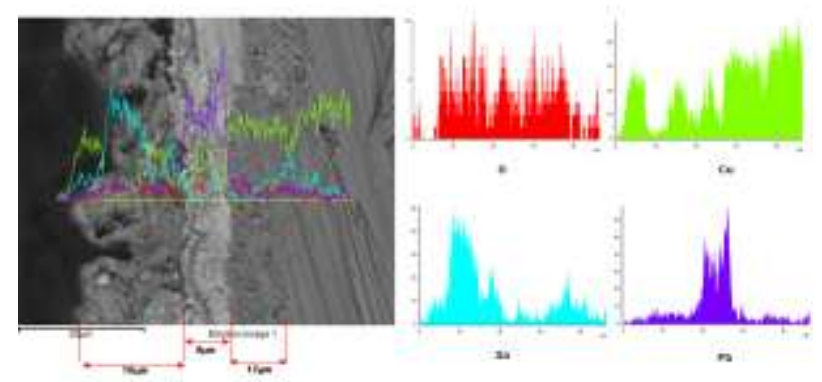

Figure 4-3. The results of EDC line scanning of the PV ribbon recovered from the spent PV module after 2-hour oxidation at the temperature of 500 ${ }^{\circ} \mathrm{C}$

[Figure 4-4] shows the results of an analysis of the chemical composition of the PV ribbon samples recovered from the spent $\mathrm{PV}$ module after 4 -hour oxidation at $500^{\circ} \mathrm{C}$ and the base material. In the oxide layer formed in the outermost part, the composite oxide layer containing mainly $\mathrm{Pb}, \mathrm{Sn}$ and a small amount of $\mathrm{Cu}$ were observed. In the next oxide layer, $\mathrm{Cu}$ and $\mathrm{Sn}$ were observed as main component with a small amount of $\mathrm{Pb}$ were observed. This indicates the oxidation outside the $\mathrm{Cu}$ progresses, so the cooper-oxide is separated because of the difference in the thermal expansion coefficient between metals and oxides. The interface of the $\mathrm{Cu}$ base material is mainly composed of $\mathrm{Cu}$, and some $\mathrm{Ag}$ has also been detected. And the innermost past is mainly composed of copper. 
Proc. of Sixth International Conference On Advances in Applied Science and Environmental Engineering - ASEE 2016
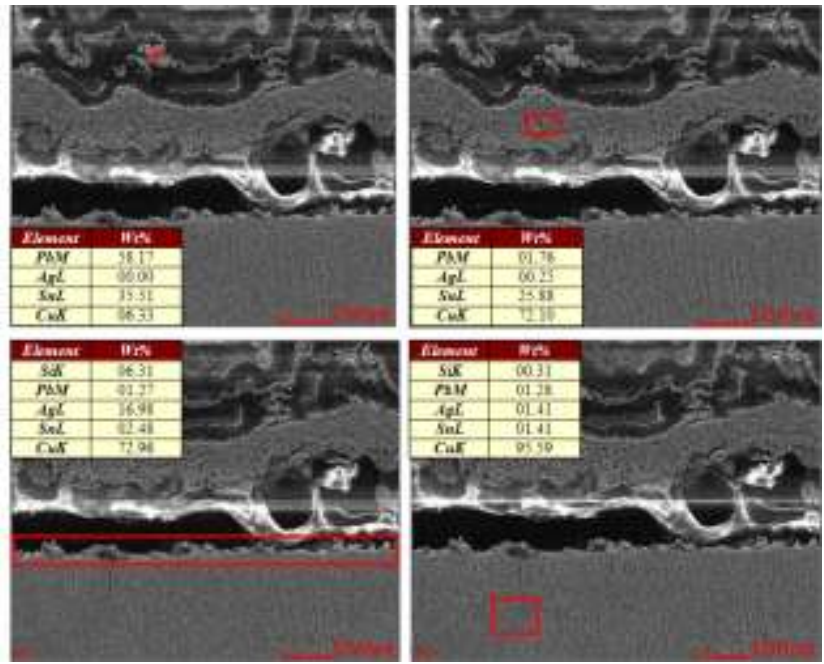

Figure 4-4. EDS component analysis results of the PV ribbon recovered from the spent PV module after 4-hour oxidation at the temperature of $500^{\circ} \mathrm{C}$

\section{v. CONCLUSION}

Heat treatment experiment was conducted to recover the valuable metals from the PV ribbon in the spent PV module. To measure the oxidation behaviors of the coating layer in the PV ribbon, 24-hour heat treatment was conducted by blowing an oxygen gas at the temperature of $100^{\circ} \mathrm{C}, 300^{\circ} \mathrm{C}$, $500{ }^{\circ} \mathrm{C}$ and $700{ }^{\circ} \mathrm{C}$. With an increase of oxidation temperature, the weight significantly increased, especially at the high temperature of $500^{\circ} \mathrm{C}$ and $700^{\circ} \mathrm{C}$, when compared with the oxidation behavior at the low temperature of $100^{\circ} \mathrm{C}$ and $300^{\circ} \mathrm{C}$.

In the oxidation condition of $500^{\circ} \mathrm{C}$ showing distinctive oxidation behavior, the oxidation behavior of the coating later according to the holding time of $1 \mathrm{hr}, 4 \mathrm{hrs}$ and $8 \mathrm{hrs}$ was observed using SEM. In the heat treatment condition of more than 4-hours at $500^{\circ} \mathrm{C}$, distinctive separation between the base material and the oxide layer was observed. Furthermore, the element distribution of the oxide layer was observed by EDS scanning line. The oxide layer and the base material could be distinguished by the shape and the composite oxide layer mainly containing $\mathrm{Sn}$ and $\mathrm{Pb}$ was formed in the oxide later formed in the outermost part. In addition, the oxide layer developed into the wisker shape, oxidizing internal $\mathrm{Cu}$, so $\mathrm{Cu}$ was detected in the oxide layer in the middle and inside part. A component analysis was conducted using EDS. As a result, $\mathrm{Pb}$ and $\mathrm{Sn}$ were observed in the oxide layer formed in the outermost part, and $\mathrm{Cu}$ content gradually increased towards the inside.

\section{Acknowledgment}

This work was supported by the Korea Institute of Energy Technology Evaluation and Planning(KETEP) and the Ministry of Trade, Industry \& Energy(MOTIE) of the Republic of Korea (No. 20163010012240)

\section{References}

[1] Max, M., Wolfgang, B., Martin, S., Andreas, M., Armin, R., Recycling paths of thin-film chalcogenide photovoltaic wasterCurrent feasible processes, Renewable Energy, 55, pp220-229, 2013

[2] Kang, S.M., Yoo, S.Y., Lee, J.N., Boo, B.H., Ryu, H.J., Experimental investigations for recycling of silicon and glass from waster photovoltaic modules, Renewable Energy, 47, pp152-159, 2013

[3] Kang, S.M., Yoo, S.Y., Lee, J.N., Boo, B.H., Ryu, H.J., Experimental investigations for recycling of silicon and glass from waster photovoltaic modules, Renewable Energy, 47, pp. 152-159.

[4] Krister. Aanesen., Stenfan. Heck., Dickon. Pinner., Solar power: Darkest before dawn, Mckinsey\&Company, pp. 2-4, 2012

[5] Wang, T.Y., Lin, Y.C., Sivakumar, R., Rai, D.K., Lan, C.W., A novel approach for recycling of lerf loss silicon from cutting slurry waster for solar cell appli-cations, Journal of Crystal Growth, 310, pp. 34034306, 2008

[6] Lee. Y. G., A study on Recovery of high purity Silicon from waste PV modules, chonnam national univ. 2014

[7] Kang S. M., Yoo S. Y., Boo B. H., Ryu H. J., Study for Recovery Silicon and Tempered Glass from Waste PV Modules, J. of Korean Inst. Resources Recycling, Vol.20 no.2, pp. 45-53, 2011

[8] Hee-Dong Jang, Dae-Sup Kil, Han-Kwon Chang, Young-Ju Cho and Bong-Gyoo Cho, Trend on the Recycling Technologies for Silicon Sludge by the Patent and Paper Analysis, J. of Korean Inst. of Resources Recycling Vol. 21, No. 4, 60-68, 2012

[9] Lee. J. S., Kang. K. H., International/Domestic Technology Status of Photovoltaic Recycling, South Korea Solar Energy Society Vol.13 No.1, pp. 3-10, 2015.6

[10] Lee. J. S., Jang. B. Y., Kim. J. S., Ahn. Y. S., Kang. G. H., Wang. J. P., Recovery of $\mathrm{Cu}$ from spent photovoltaic ribbon in solar module, Journal of Korean Inst. of resources recycling, Vol.22, No.5, pp. 5055, 2013

[11] Bruton, T.M., 1995 : Production of high efficiency nomocrystalline silicon solar cell, Renewable Energy, 6, pp. 299-302.

[12] Mcdonald, N.C., Pearce J.M., 2010 : Producer responsibility and recycling solar photovoltaic modules, Energy Policy, 28, pp. 70417047.

[13] Fthenakis, V.M., 2000 : End-of-life management and recycling of PV modules, Energy Policy, 20, pp. 1051-1058.

[14] Miles, R.W., Hynes, K.M., Forbes, I., 2005 : Photovoltaic solar cell: an overview of state-of-the-art cell development and environmental issues, Progress in Crystal Growth and Characterization of Materials, 51, pp. 1-42. 